\title{
非外傷性上腕骨頭壊死の治療経験
}

長崎大学医学部整形外科

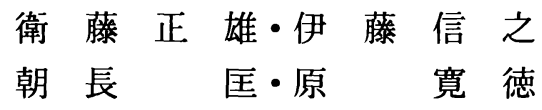

M. E. Rabbi

\section{Follow-up Study of the Avascular Necrosis of the Humeral Head}

by

\author{
Masao Eto, Nobuyuki Ito, Tadashi Tomonaga, \\ Hironori Hara and Mohammad Ehsanur Rabbi \\ Department of Orthopaedic Surgery, Nagasaki University School of Medicine
}

\begin{abstract}
The avascular necrosis of the humaral head is less common than femoral head necrosis. The purpose of this study is to evaluate the patients with atraumatic avascular necrosis of the humeral head, clinicaly and radiologicaly.

Six patients (11 shoulders) were examined. Among them 4 patients had femoral head necrosis as well. Predisposing causes were steroid therapy in 6 shoulders of 3 patients and caisson disease in 5 shoulders. There were 4 males and 2 females. The average age was 47 years ( 33 to 59 years). The mean follow-up period was 7 years 5 months. Six shoulders were treated coservatively and in 5 shoulders arthroplasty was performed.

In the radiographic examination, 10 shoulders had normal articular surface (stage I ), one had deformed articular surface (stage II) and no osteoarthritis (stage III) at first visit. Progression of the radiographic stage was observed in 9 shoulders. Clinical results were evaluated by JOA score. The average JOA score of non-operated patients at initial examination was 88.7 and at the recent examination that was 87.8 . On the other hand, in patients with arthroplasty the average JOA score improved from 54.8 to 84.7 . (excluding one case).

Initially subchondral translucent line or linear opacity were seen in most of the cases which were progressive. Patients with severe pain (JOA score below 70 ) required arthroplasty and a satisfactory results were obtained except one case.
\end{abstract}

Key words : avasucular necrosis of the humeral head (上腕骨頭壊死), clinical rusults (臨床成績), radiographic findings ( $\mathrm{X}$ 線学的所見), arthroplasty（人工骨頭置換術）

は じめに

上腕骨頭壊死は種々の原因で発症するが，非外傷性 壊死は比較的まれである. 今回, 6 例 11 肩の非外傷 性上腕骨頭壊死の治療成績と X 線学的変化について 調查した。
対

対象は非外傷性上腕骨頭壊死 6 例 11 肩である。男 性 4 例 7 肩，女性 2 例 4 肩で，最終調查時年齢は平均 47 歳（33～59 歳），追跡調查期間は平均 7 年 5 力月 （ 6 力月〜14 年）であった.

上腕骨頭壊死の発症原因はステロイド性が 3 例 6 肩 


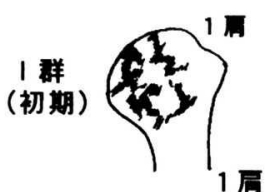

熄状理化

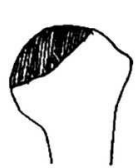

分简状西化的

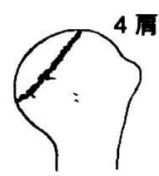

㩆状项化保

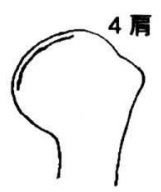

軟骨下透亮像 限局性石欧化像

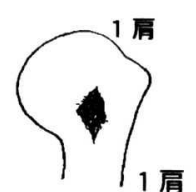

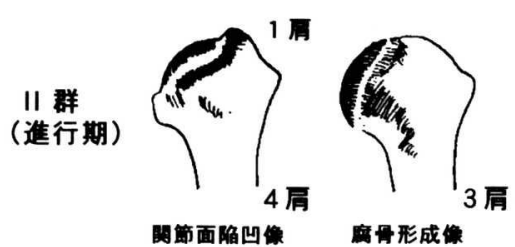

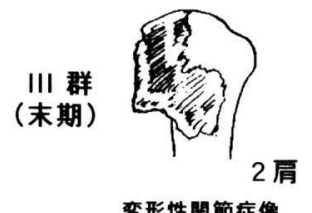

図 1 上腕骨頭壊死の X 線分類

(Medical Research Council, 1966)

図の右上に初診時の肩数を右下に最終調查時または術前 の肩数を示す.

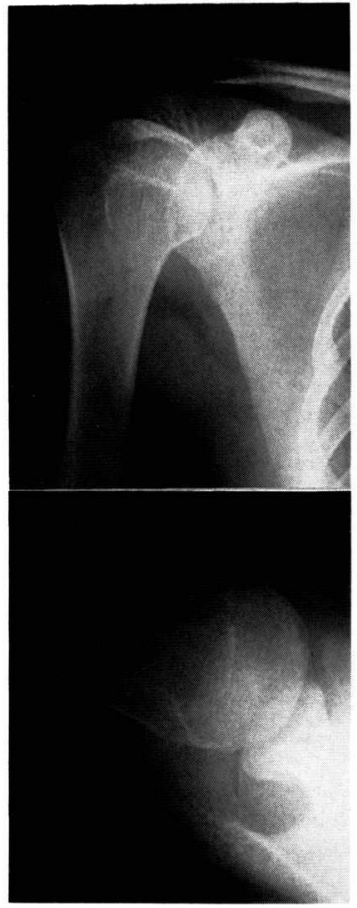

a

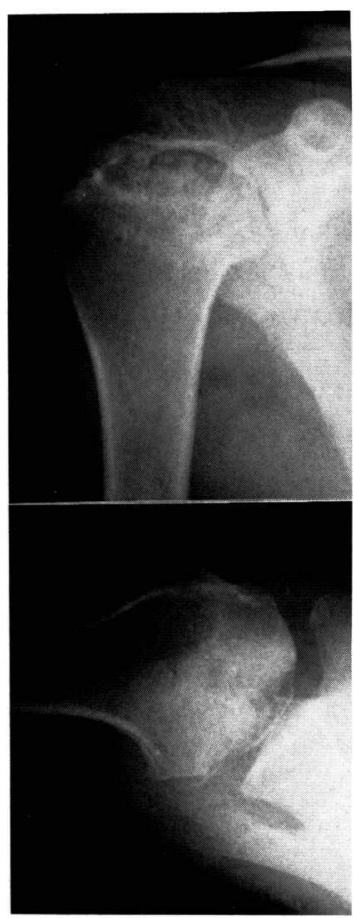

b
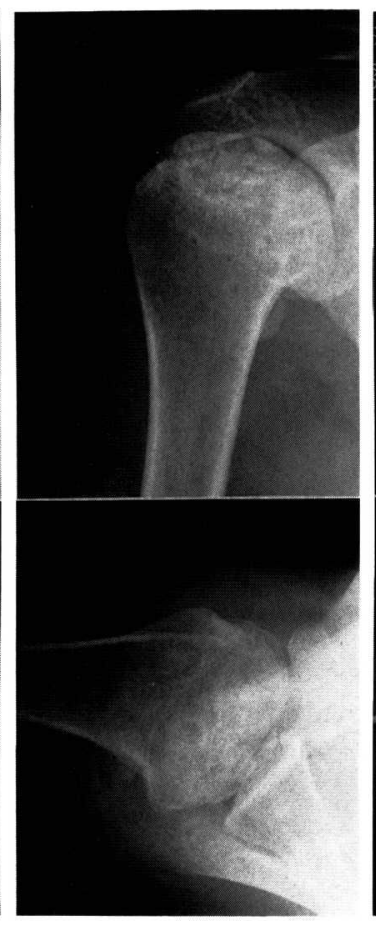

c

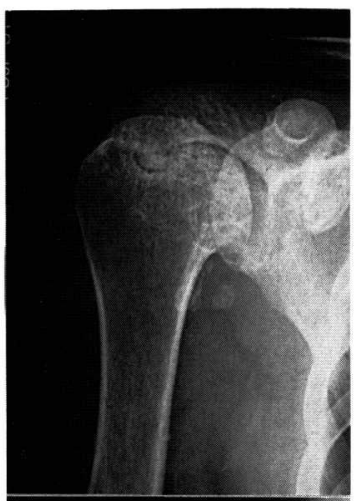

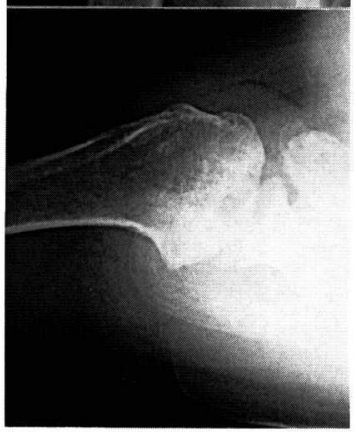

d

図 2 症例 133 歳, 女性, SLE, 右肩

a. 20 歳, 初診時. 軟骨下透亮像を認めた.

JOA score は 98 点であった.

b. 初診より 1 年 7 カ月後, 関節面陷回像に進行した.

c. 初診より 5 年後, 前後像での関節面の陥凹の程度は改善しているが, 軸射像での变形は残っ ており腐骨形成像を呈していた。

d. 初診時より 13 年後, 腐骨形成像を呈しているが, 軸射像では関節面の不整像が改善してい る. JOA score は 81 点であった. 


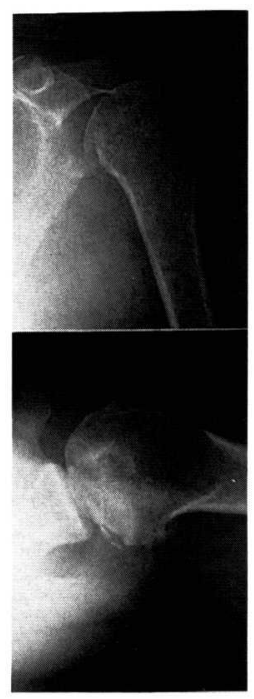

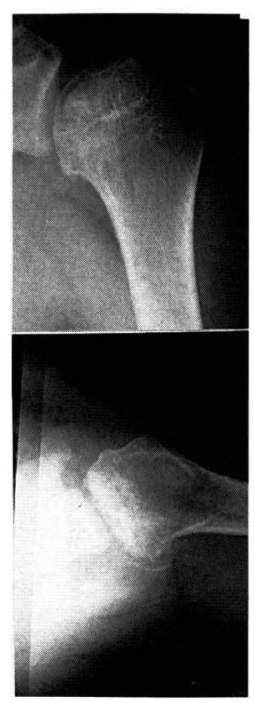

$\mathrm{b}$

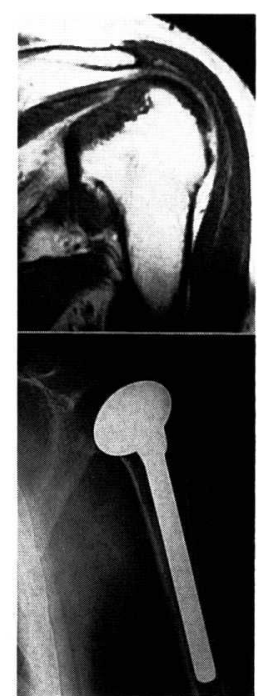

c

図 3 症例 238 歳, 男性, ベーチェット病, 左肩

a 、初診より 8 力月後, 関節面陥凹像を認めた.

b. 初崄より 2 年後, 変形性関節症像へと壊死は進行し, JOA score は 64 点であった.

c. MRI でも関節面の変形と壊死の範囲がはっきり認められた. 人工 骨頭置換術後 JOA score は8 85 点に改善した.

（男性 1 例, 女性 2 例) で, 症状発現までのステロイ ド服用期間は平均 4.7 年（ $2 \sim 12$ 年）であった。 全 例に大腿骨頭壊死の合併が認められ，そのうち 2 例 3 股に人工骨頭置換術が行われていた，原疾患はSLE, ベーチェット病, 下垂体腫瘍 (下垂体切除) であった. 減圧症は 3 例 5 肩で, 1 例に大腿骨頭壊死の合併がみ られた。

治療方法は保存的経過観察例が 3 例 6 肩で, 経過観 察期間は平均 8 年 7 力月（ $5 \sim 14$ 年）であった。観 血的治療例は 3 例 5 肩（ベーチェット病 1 例 2 肩, 減 圧症 2 例 3 肩）で, 術後観察期間は平均 4 年 6 力月 ( 6 力月〜 11 年) であった. 人工骨頭置換術を 5 肩に 行った. そのうちの 1 肩は骨頭穿孔術後, 人工骨頭置 換術を行ったが疼痛の改善を認めず，最終的に人工関 節置換術を行った.

\section{方法}

X 線分類は Medical Research Council（1966 年） の骨壊死分類 ${ }^{5)}{ }^{8)}$ に準じて石部ら ${ }^{3)}$ のように分類し, 初診時からの経過を観察した（図1）。また, 臨床成
績は日整会肩関節疾患治療成績判定基準（JOA score）を用いて評価した.

$$
\text { 結果 }
$$

初診時の X 線像を分類すると, I 群初期の塊状硬 化像が 1 肩, 線状硬化像が 4 肩, 軟骨下透亮像が 3 肩, 限局性石灰化像が 1 肩であった。ささらに II群進行期の 関節面陥凹像が 2 例で， III群末期の変形性関節症像を 呈する例はなかった，最終調查時，または人工骨頭置 換術前の X 線像は I 群初期の塊状硬化像が 1 肩, 限 局性石灰化像が 1 肩, II 群進行期の関節面宿像 4 肩, 腐骨形成像が 3 肩， III群末期の変形性関節症像が 2 肩 であった．塊状硬化像と限局性石灰化像の各 1 肩を除 き， $\mathrm{X}$ 線像上病期の進行を認めた（図 1 ）。 また $\mathrm{X}$ 線 像は前後像よりも軸射像のほうが骨頭の陥凹が分かり やすい例が多かった。

JOA score は保存的治療例では初診時平均 88.7 点 (70 98 点), 最終調查時平均 87.8 点 (81〜95 点) で あり，両者に有意差は認めなかった。しかし経過観察 期間中には疼痛の寛解増悪を認めていた. 


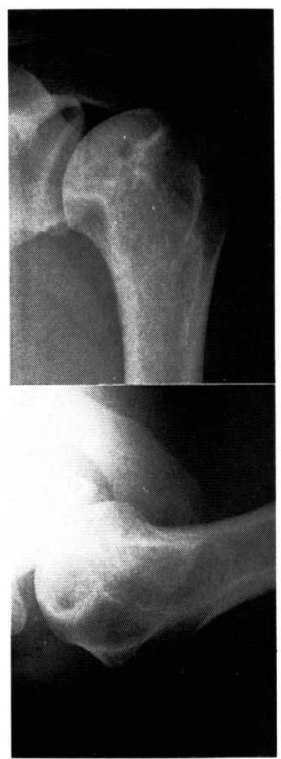

a

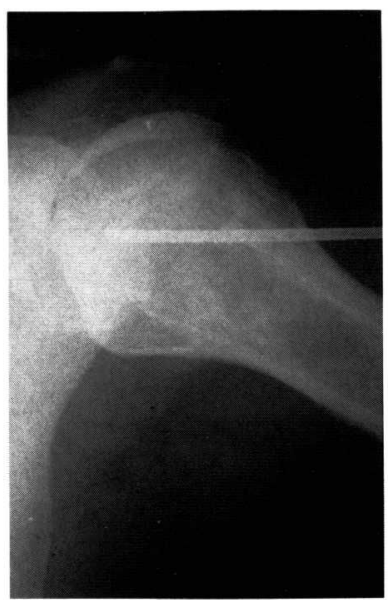

b

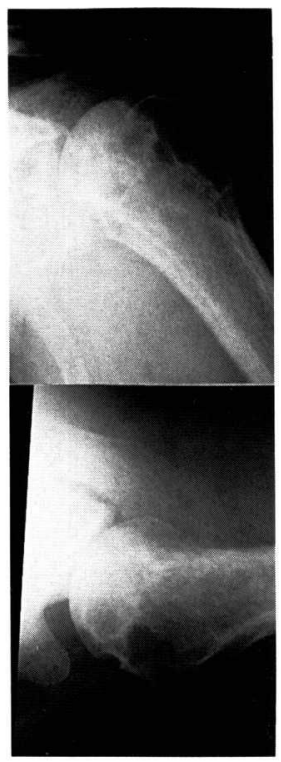

c

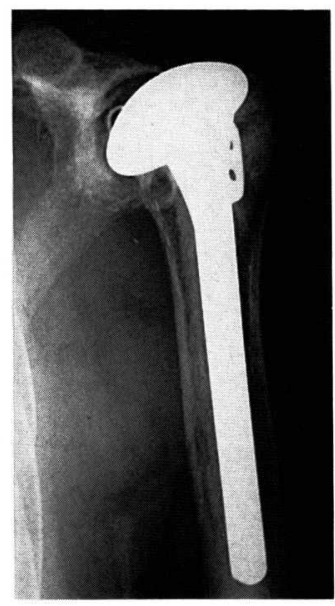

d

図 4 症例 357 歳, 男性, 隇圧症, 左肩

a . 46 歳初診時, 骨頭に線状硬化像を認めた.

b. 初診より 3 力月後, 骨頭穿孔術を行った.

c，骨頭穿孔術より 5 力月後，壊死は進行し関節面陥凹像を認めた．JOA score 44 点で人工骨頭 置換術を行ったが, 疼痛・機能ともに改善がみられず, 2 年 6 力月後人工関節に再置換した.

d. 57 歳最終調查時, 人工関節置換術後である.JOA score は 48 点で改善がみられなかった。

観血的治療例では術前平均 54.8 点（44 66 点）が, 術後は平均 71.4 点（48９5 点）に改善していた。し かし， 1 例 2 肩は症例 3 に示すように原因がよくわか らない疼痛があり, 成績は不良であった。

\section{症例}

症例 $1: 33$ 歳女性, SLE で, 15 年前からステロイ ドを服用している，両側の股関節は大腿骨頭壊死のた め 19 歳時に人工骨頭置換術が行われた，右肩痛が 20 歳頃より出現. その時点の X 線像では, 軟骨下透亮 像を認めた。 その後は関節面陥凹像, 腐骨形成像と X 線像上壊死は進行している，現在，腐骨形成と関節面 の不整像は認められるが，日常生活での痛みのみで JOA score は 81 点である（図 2 ）。また左肩同様の 経過をたら゙っており, JOA score は 81 点である.

症例 $2: 38$ 歳, 男性. ベーチェット病で, 14 年間 ステロイドを服用している．右肩痛出現から 1 力月後 の X 線像で, 軟骨下透亮像之関節面陥凹が認められ, 人工骨頭置換術をおこない, 術前 JOA score 66 点が
術後 2 年 5 力月の現在 95 点と改善した。左肩は初診 時 X 線像で軟骨下透亮像を認め, 8 力月後には関節 面陷凹像に， 2 年後には変形性関節症像へ之進行した. MRI でも骨頭の変形と骨壊死部分がよくわかる，術 前 JOA score 64 点が人工骨頭置換術後 6 力月の現在 85 点に改善した（図3）。また手術は行っていないが, 両側の大腿骨頭壊死の合併を伴っている.

症例 $3: 57$ 歳, 減圧症の男性である。初診時左肩 痛あり, 骨頭に硬化像を認め JOA score は 68 点であっ た，骨穿孔術を行ったが，術後 5 力月時には関節面陥 凹像を認めた。疼痛と可動域制限が強く JOA score は 44 点と覀くなった，人工骨頭置換術を行ったが症 状改善せず，人工関節に再置換した，術中所見では人 工骨頭の loosening は認めず, 関節窩にも特に異常 は認めなかった。 人工関節置換術後も症状の改善は少 なく, JOA score は 48 点である（図 4 ）。右肩にも 骨頭壊死を生じ（JOA score 46 点）人工骨頭置換術 を行ったが, 術後 2 年 2 力月の現在, 疼痛が強く JOA score 53 点とほとんど改善がみられていない. 
この症例は術後の疼痛の原因がよくわかっておらず, 治療に難渋している症例である.

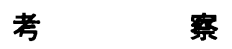

骨頭壊死の原因には種々のあのがあげられる．非外 傷性上腕骨頭壊死はなかであ減圧症やステロイド性, アルコール性で発生頻度が高いとされている，自験例 では全例減圧症とステロイド性によるものであった。 また上腕骨頭壊死はしばしば大腿骨頭壊死に合併する が，諸家の報告ではステロイド性では $6 〜 19 \%$ であり， 減圧症では $67 \%$ の報告がある ${ }^{3) 6}$. 我々の症例では上 腕骨頭壊死に合併する大腿骨頭壊死の頻度はステロイ ド性では $100 \%$ に，減圧症では $33 \%$ に認められた。

骨頭壊死の初期 X 線像は諸家の報告")では 1）軟 骨下透亮像，2）帯状硬化像，3）帯状透過陰影像,

4) 関節面不整像，5）頚部骨梁萎縮像などがあげら れている. 特にステロイド性では軟骨下透亮像を初期 に認めることが多いといわれている．自験例であステ ロイド性骨頭壊死 6 肩中, 軟骨下透亮像が 3 肩之最も 多かった． 2 肩は線状（帯状）硬化像，1肩は既に進 行期の関節面陥凹像を呈していた，全例経過観察中，

$\mathrm{X}$ 線像での壊死の程度は進行していた。 また減圧症 では初診時 $\mathrm{X}$ 線像は線状硬化像 2 肩, 限局性石灰化 1 肩，塊状硬化 1 肩，関節面樎凹像 1 肩であった，そ のうち限局性石灰化と塊状硬化を呈した 1 例 2 肩は $\mathrm{X}$ 線像上進行がなく, JOA score も 85 点と 98 点と 良好で観血的治療は行っていない，腐骨形成および関 節症性変化に及んだ 3 肩に手術を行った.

一般に，壊死に宿った骨頭は自然治撚することはほ とんどなく, 特に関節面障害型では病变が進行する例 が多い，鳥单ら ${ }^{9)}$ は減圧症では分節状硬化型が発生し やすいが，この型はあまり進展をみせず，線条硬化型 のほうが腐骨形成型を経て变形性関節症に進行しやす いと述べている，自験例では分節状硬化を示す例はな かったが，線条硬化型は 2 例とも腐骨形成型に進行し ていた。一方，ステロイド性では軟骨下透亮型 3 例, 線条硬化型 2 例ともにX 線像上の進行を認めており, やはり関節面障害型では病变が進行することがわかっ た.

治療はまず保存的治療が選択され，消炎鎮痛剂を投 与したりヒアルロン酸の関節内注入を行うこともある が，一度壊死に陥った骨頭の自然治瘉の可能性は少な い。しかし骨壊死が起きても関節面に変化が起こらな
いと無症状のまま経過することが多く，また関節面に 軽度の変形が生じても荷重関節でないことから, 可動 制限はあってあ比較的疼痛が軽く観血的治療の対象之 なることは少ない，我々の手術した症例は JOA score が術前 44 66 点（平均 54.8 点）で保存的治療例には 70 点以下の例がないことから, JOA score が 70 点以 下であることが手術適応の一つの目安となると考える. 手術療法は線状硬化像や軟骨下透亮像などの初期の段 階では骨穿孔術や骨移植術が勧められるが，まとまっ た報告例は少ない，L'Insalataら“は関節面がわずか に適合していない程度の軟骨下骨折を認める 4 例に骨 穿孔術を行ったが, 壊死の進行を止めることができず arthroplasty を行ったと報告している，我々も減圧 症による線状硬化像の 1 例に骨穿孔術を行ったが, 効 果はなく人工骨頭置換術を行っている，かなり早期の 症状でなければ骨穿孔術の効果は薄いと考えられる.

一方, 症状が進行した例では人工骨頭置換術や人工関 節置換術が行われることが多く, 良好な結果を得てい $3^{1) 2}$. 我々も 3 例 5 肩に人工骨頭置換術を行い, 原 因のつかめない疼痛を訴える 1 例 2 肩を除き結果は良 好であった，我々はまず保存的治療を行いつつ経過を 観察し, 強い疼痛が持続し機能障害を伴うような例に は, 関節窩に変形が及ぶ前に人工骨頭置換術を行うこ とが必要であると考えた。

\section{ま と め}

1. 非外傷性上腕骨頭壊死 6 例 11 肩の JOA score と X 線像の変化について調べた。 4 例に大腿骨頭壊 死の合併を認めた。 4 例 5 肩に人工骨頭置換術を行っ た.

2. 手術例の平均 JOA score は術前 54.6 点が術後 71 点に改善したが，1例に改善がみられなかった。 保存的治療例では初診時が 88.7 点, 最終調查時 87.8 点で JOA score に差はなかった。

3. 初期 X 線像は軟骨下透亮像や線状硬化像を示 す例がほとんよ゙で，このような例では全例 X 線像上 の進行を認めた．また前後像よりあ軸射像のほうが骨 頭の障害がわかりやすい例が多く, 二方向撮影で十分 検討することが大切である.

4. $\mathrm{X}$ 線像上の進行は認めても, 疼痛や機能にほ とんど变化を認めない例ああり, まず保存的に経過を 観察し, 持続する強い疼痛を伴う場合には人工骨頭置 換術の適応となると考える。 


\section{参考文献}

1）渥美 敬ほか：特発性大腿骨頭壊死に合併する上腕骨 頭壊死について. 肩関節, $6: 18-26,1982$.

2) Crues, R. L. : Experience with Steroid - induced Avascular Necrosis of the Shoulder and Etiologic Considerations Rigarding Osteonecrosis of the Hip. Clin. Orthop., $130: 86-93,1978$.

3）石部基実ほか：当科における非外傷性上腕骨頭壊死に ついて. 肩関節, $10: 165-167,1986$.

4) L'Insalata J. C. et al. : Humeral head osteonecrosis : Clinical course and radiographic predictors of outcom. J. Shoulder Elbow Surg., 5 : 355-361, 1996.
5) McCallum R. I. and Walder D. N. : BONE LESION IN COMPRESSED AIR WORKERS. With Special Reference to Men who Worked on the Clyde Tunnels 1958 to 1963. J. Bone and Joint Surg., 49-B : 207-235.

6）織田 格ほか：減圧症による上腕骨頭無腐性壊死一區 床像と X 線像の分析一。局関節，17:274-279，1993.

7）高岸憲二, 杉岡洋一, 喜名政浩 : 非外傷性上腕骨頭壊 死のレ線的検討. 肩関節, $7: 38-42,1983$.

8）鳥巣岳彦, 真角昭吾 : 上腕骨頭壊死, 新臨床整形外科 全書. 6-B. 金原出版. 東京, 98-109, 1981.

9）鳥巣ほか：減圧症と骨関節の変化, 4. 潜水病性骨病 変の経年的変化についてー潜水士 127 名の 7 年間追跡調 查. 臨床整形外科, $9: 308-318,1974$. 